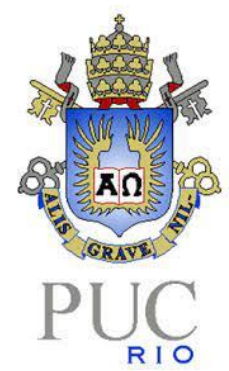

PONTIFICIA UNIVERSIDADE CATÓLICA DO RIO DE JANEIRO

\title{
Liderança e clima organizacional: a busca de uma boa saúde dos restaurantes
}

\author{
Lucca De Faria Nunes \\ Orientador(a): Marcelo Piñeiro \\ Trabalho de conclusão de curso \\ ESCOLAS DE NEGÓCIOS DA PUC RIO - IAG \\ DEPARTAMENTO DE ADMINISTRAÇÃO \\ Graduação em Administração de Empresas
}


Rio de Janeiro Junho de 2021.

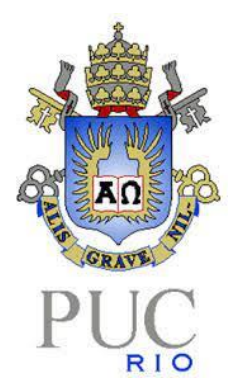

Lucca de Faria Nunes

\section{Liderança e clima organizacional: a busca de uma boa saúde dos restaurantes}

Trabalho de Conclusão de Curso

Trabalho de Conclusão de Curso, apresentado ao programa de graduação em Administração da PUCRio como requisito parcial para a obtenção do título de graduação em Administração.

Orientador(a): Marcelo Piñeiro

Rio de Janeiro 
Junho de 2021

\section{Agradecimentos:}

É com grande prazer e felicidade que inicio agradecendo a todos e a instituição PUCRio e ao IAG, que me auxiliaram durante este longo processo de elaboração da monografia.

Agradeço imensamente e especialmente ao meu orientador Marcelo Piñeiro, pela liberdade, confiança e entusiasmo incessante na minha trajetória como aluno. Ele foi fundamental durante todo o percurso, sendo sempre companheiro e acolhedor, trazendo as críticas necessárias e construtivas para o avanço do trabalho.

Agradeço à minha família, ao amor e apoio imensurável e a alegria de cada dia, meu pai Israel Nunes, minha mãe Flavia de Faria, meu padrasto Stéphane Rocton, e minha irmã Olivia de Faria.

Agradeço especialmente a minha maravilhosa tia, Lorena da Silva, que me ajudou na parte do português e regras da língua.

Agradeço imensamente a todos os entrevistados, por disponibilizarem seu tempo e paciência, para o melhor entendimento da minha pesquisa. 


\section{Resumo:}

Nunes, Lucca de Faria. Liderança e organização para uma boa saúde de restaurante.

Rio de Janeiro, 2021. Trabalho de conclusão de curso - departamento de Administração. Pontifícia Universidade Católica do Rio de Janeiro.

A liderança é uma das habilidades mais crucias no desenvolvimento do clima organizacional de um restaurante. Diante disso, elaborou-se o seguinte objetivo geral para esta pesquisa: identificar os impactos ocasionados pelo tipo de liderança desenvolvida em restaurantes franceses e comparar os restaurantes do Rio de Janeiro e do Tahiti. A pesquisa buscou analisar os conceitos de liderança, seus modelos mais utilizados em restaurantes, a sua importância e o ambiente organizacional que a rodeia. Por fim, analisar a gastronomia francesa, pois o estudo foi focado na liderança dos restaurantes franceses. Os dados foram coletados por meio de uma pesquisa qualitativa, utilizando como procedimentos metodológicos uma abordagem descritiva e exploratória associada à pesquisa bibliográfica em livros, artigos, teses e dissertações. A pesquisa qualitativa foi realizada através de entrevistas com cinco líderes de restaurante, localizados no Rio de Janeiro e no Tahiti, os quais responderam cinco perguntas relacionadas a tipos de liderança, clima organizacional e organização do restaurante. Além das entrevistas, foi realizado um questionário on-line, direcionado a chefes e cozinheiros, com o objetivo de compreender como os funcionários se relacionam entre si e com suas tarefas. Os resultados apresentaram uma comparação entre o modelo de liderança brasileiro e francês, e uma boa liderança está no equilíbrio entre os dois modelos. Durante as entrevistas, eles demonstraram que estão insatisfeitos com o clima organizacional do restaurante, ou seja, a relação líder e funcionários estava precária, apresentando desconforto e desmotivação. Conclui-se, por meio da amostra coletada, que o objetivo geral foi contemplado, ou seja, foi possível identificar os impactos ocasionados pelo tipo de liderança desenvolvida em restaurantes.

Palavras chaves: Liderança. Ambiente Organizacional. Cozinha Francesa. 


\section{Abstract:}

Nunes, Lucca de Faria. Leadership and organization for the good health of a restaurant. Rio de Janeiro, 2021. Course completion work - Administration department. Pontifical Catholic University of Rio de Janeiro.

Leadership is one of the most crucial skills in developing a restaurant's organizational climate. Therefore, the following general objective for this research was elaborated: to identify the impacts caused by the type of leadership developed in French restaurants and to compare the restaurants in Rio de Janeiro and Tahiti. The research sought to analyze the concepts of leadership, its most used models in restaurants, its importance and the organizational environment that surrounds it. Finally, analyze French cuisine, as the study was focused on the leadership of French restaurants. Data were collected through a qualitative research, using as methodological procedures a descriptive and exploratory approach associated with bibliographical research in books, articles, theses and dissertations. The qualitative research was carried out through interviews with five restaurant leaders, located in Rio de Janeiro and Tahiti, who answered five questions related to types of leadership, organizational climate and restaurant organization. In addition to the interviews, an online questionnaire was conducted, aimed at chefs and cooks, in order to understand how employees relate to each other and to their tasks. The results showed a comparison between the Brazilian and French leadership models, and good leadership is in the balance between the two models. During the interviews, they demonstrated that they are dissatisfied with the organizational climate of the restaurant, that is, the relationship between leaders and employees was precarious, showing discomfort and lack of motivation. It is concluded, through the collected sample, that the general objective was contemplated, that is, it was possible to identify the impacts caused by the type of leadership developed in restaurants.

Keywords: Leadership. Organizational environment. French kitchen. 


\section{Sumário}

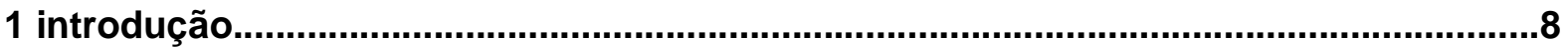

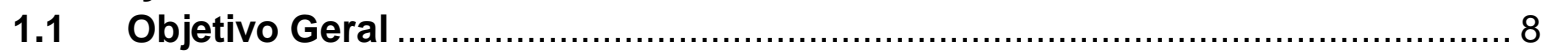

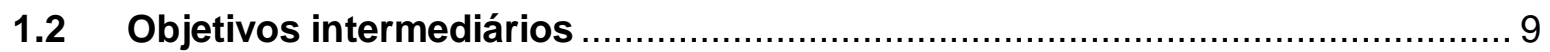

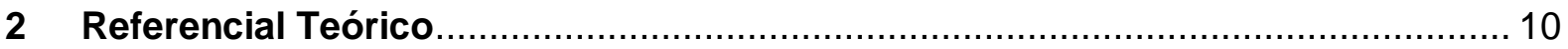

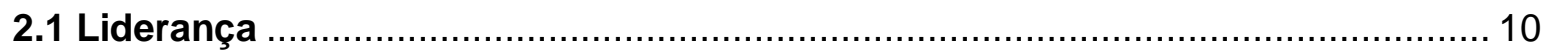

2.1.1 Importância da Liderança ............................................................... 11

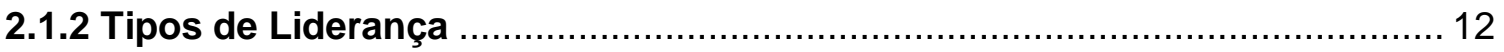

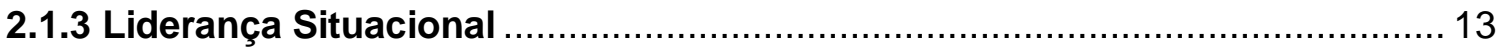

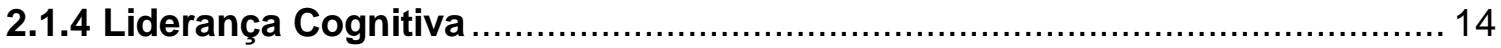

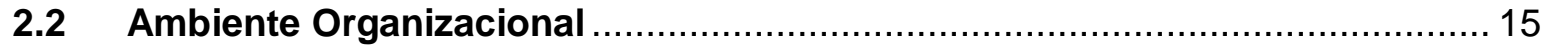

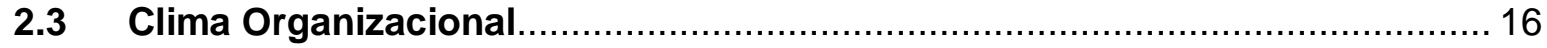

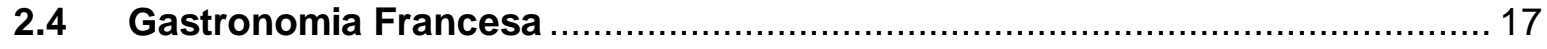

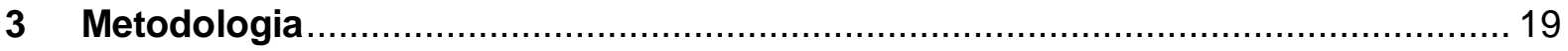

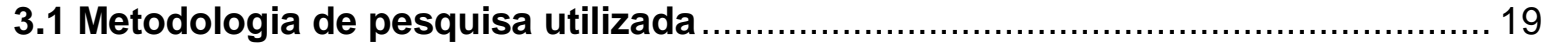

3.2 Procedimento e instrumento de coleta de dados ........................................ 21

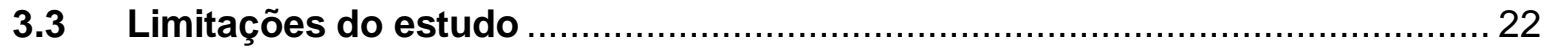

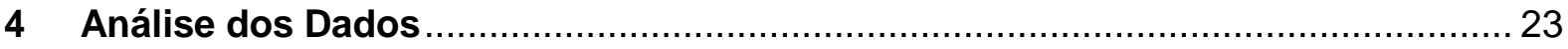

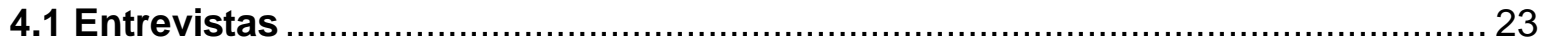

4.1.1 Que tipo de liderança combina mais com você e como é o modelo de

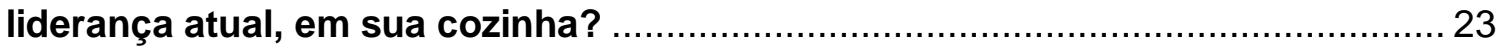

4.1.2 Qual o nível de satisfação dos líderes quanto ao clima organizacional? ..... 25

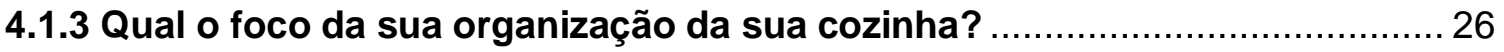

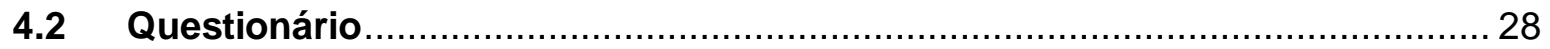

$4.3 \quad$ Análise de Entrevistas e Questionários .................................................... 29

4.3.1 Comparação do estilo de liderança entre restaurantes brasileiros e

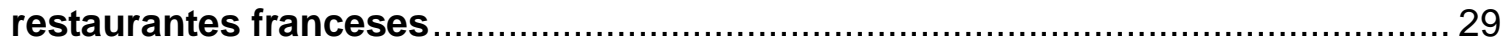

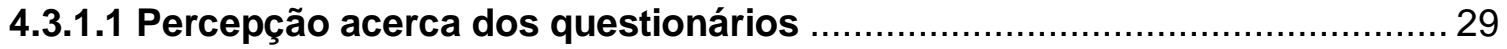

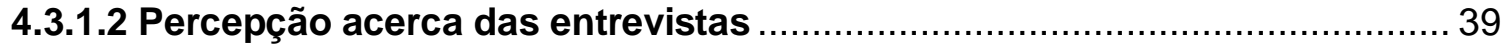

4.3.2 Impacto do estilo de liderança estudado sobre o clima organizacional ....... 40

4.3.2.1 Percepção acerca dos questionários …................................................ 40

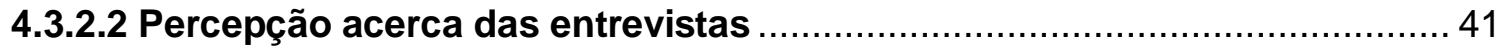

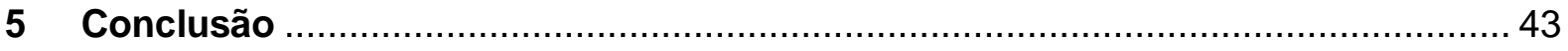




\section{Lista de gráficos}

Gráfico 1: Gráfico questionário chefe francês

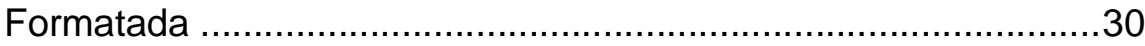

Gráfico 2: Gráfico questionário chefe brasileiro

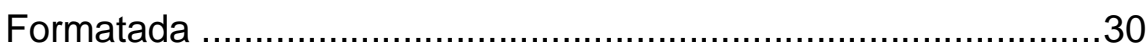

Gráfico 3: Gráfico questionário cozinheiro brasileiro

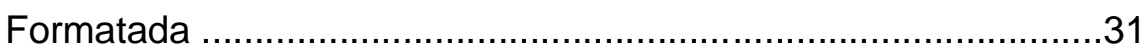

Gráfico 4: Gráfico questionário cozinheiro francês

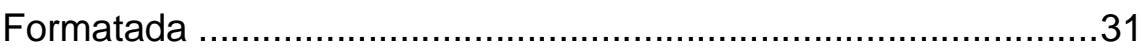

Gráfico 5: Gráfico questionário cozinheiro francês

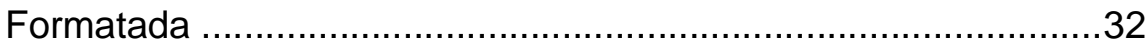

Gráfico 6: Gráfico questionário cozinheiro francês

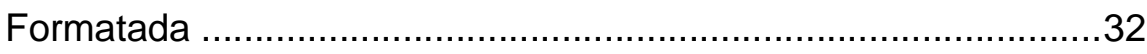

Gráfico 7: Gráfico questionário chefe brasileiro

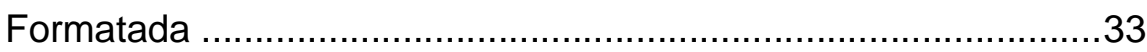

Gráfico 8: Gráfico questionário cozinheiro brasileiro

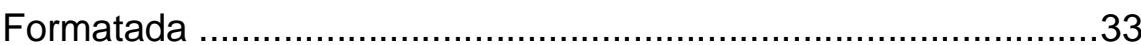

Gráfico 9: Gráfico questionário cozinheiro francês

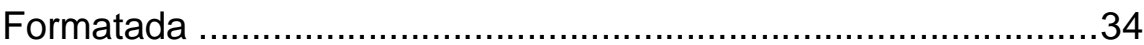

Gráfico 10: Gráfico questionário cozinheiro francês

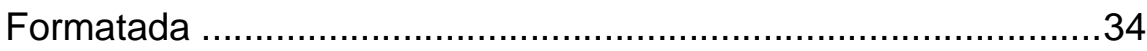

Gráfico 11: Gráfico questionário cozinheiro brasileiro

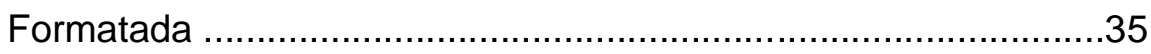

Gráfico 12: Gráfico questionário cozinheiro brasileiro

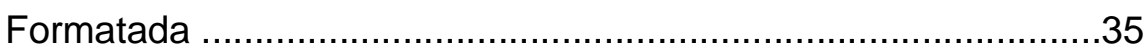

Gráfico 13: Gráfico questionário cozinheiro francês

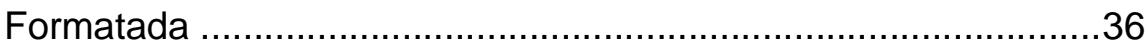

Gráfico 14: Gráfico questionário cozinheiro francês

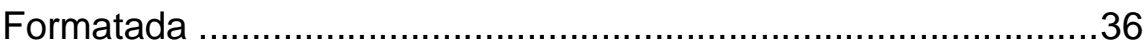

Gráfico 15: Gráfico questionário cozinheiro brasileiro

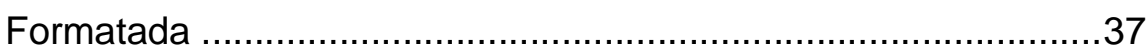

Gráfico 16: Gráfico questionário cozinheiro brasileiro

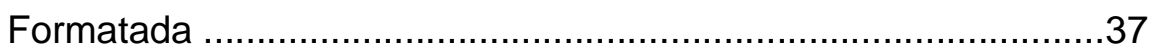

Gráfico 17: Gráfico questionário cozinheiro francês 


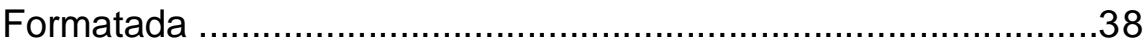

Gráfico 18: Gráfico questionário cozinheiro francês

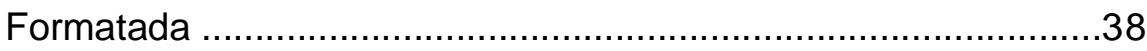

Gráfico 19: Gráfico questionário chefe brasileiro

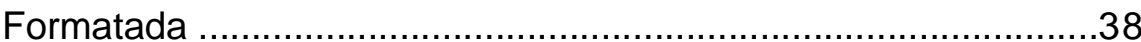

Gráfico 20: Gráfico questionário cozinheiro brasileiro

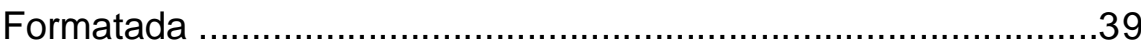




\section{Introdução}

Em um mercado gastronômico cada vez mais exigente e competitivo, torna-se imprescindível que os restaurantes invistam no desenvolvimento do seu empreendimento. Assim, uma maneira estratégica para obter resultados positivos é por meio da implantação de um modelo de liderança eficaz. Nesse sentido, a forma como a cozinha é liderada se torna um dos principais ativos do restaurante.

Para tanto, foi realizado um estudo sobre estilos de liderança e seus resultados em restaurantes. Na teoria sobre os estilos de liderança afirma Chiavenato (2003, p.124), "São teorias que estudam a liderança em termos de estilos de comportamento do líder em relação aos seus subordinados. A abordagem dos estilos de liderança se refere àquilo que o líder faz, isto é, o seu comportamento de liderar".

A elaboração deste trabalho tem como motivação a necessidade de entender a situação das lideranças presentes nos restaurantes franceses, no Rio de Janeiro e do Tahiti, Polinésia Francesa. Muitas vezes, a liderança implantada no estabelecimento ocasiona estresse e desinteresse nos funcionários, fazendo-os trabalhar sem paixão e dedicação, até mesmo afetando sua produtividade, como será observado.

Ainda, os efeitos do comportamento dos líderes de restaurante é algo visível pelos clientes, dessa forma, o cliente percebe no resultado do seu atendimento, logo esse tema é de extrema relevância, para o bom funcionamento de um restaurante.

\subsection{Objetivo Geral}

Assim, o objetivo geral desse artigo foi: identificar os impactos ocasionados pelo tipo de liderança desenvolvida nos restaurantes franceses, no Tahiti, como o Coco's, White e Lycée Hôtelier e du Tourisme e comparar com os restaurantes da zona sul do Rio de Janeiro, como Le Cordon Bleu restaurante, o instituto Le Cordon Bleu escola de culinária, Oteque e uma cozinha particular do chefe Frederic Monnier. Comparar os estilos de liderança de cada chefe, observando as vantagens e desvantagens de cada forma de trabalho. 


\subsection{Objetivos intermediários}

Com intuito de auxiliar o melhor discernimento da proposta, elaborou-se os seguintes objetivos intermediários: Identificar qual tipo de liderança que melhor funciona nos restaurantes e relatar o grau de satisfação dos chefes e cozinheiros em relação ao clima organizacional resultante de sua liderança.

Este artigo divide-se em cinco partes, a saber: A primeira registra a introdução, com a motivação, justificativa e objetivos; A segunda examina-se o referencial teórico; A terceira descreve-se a metodologia; A quarta apontam-se as análises dos resultados e por fim, a quinta parte, as considerações finais sobre o assunto em estudo.

Com isso, como pergunta relacionada ao objetivo geral, coloca-se: Quais os impactos ocasionados pelo tipo de liderança desenvolvida nos restaurantes de comida francesa? 


\section{Referencial Teórico}

O setor gastronômico carioca, é um setor que está constantemente lidando com pessoas, tanto seus clientes quanto seus colaboradores, e para isso funcionar, uma liderança e uma organização eficazes são essenciais. Com isso, esta seção está dividida em duas partes, em que a primeira aborda a questão e importância dos tipos de liderança e, logo em seguida, a segunda aborda assuntos referentes ao ambiente organizacional das cozinhas.

\subsection{Liderança}

Como um conceito geral e simplificado, pode-se afirmar que liderança é o processo de conduzir um grupo de pessoas e transformá-lo em uma equipe que gera resultados positivos. Ainda, é a habilidade de motivar e influenciar os liderados, de forma ética e positiva, de forma que contribuam voluntariamente e com entusiasmo para alcançarem os objetivos da equipe e da organização.

A liderança está associada a estímulos, incentivos e impulsos que podem provocar a motivação nas pessoas para a realização da missão, da visão e dos objetivos empresariais. Liderança, tal como motivação, nos remete às questões mais subjetivas dos seres humanos, aquelas que dizem respeito a nossas entranhas, ao que nos move ao que faz sentido para nós, aquilo a que atribuímos significado (MARQUES et al, 2013).

Liderar é o ato e a capacidade de influenciar pessoas que estão a sua volta a exercerem atividades propostas, da melhor forma possível, garantindo assim a cooperação, bem como o alcance dos objetivos previamente estabelecidos (WRIGHT, 2011).

A liderança é necessária em todos os níveis organizacionais e áreas funcionais. Wright (2011) comenta que os gestores dos níveis mais elevados nas empresas, são os principais responsáveis pelo desempenho organizacional, e aponta ainda que a liderança estratégica é cada vez mais importante nas instituições. Contudo, existem fatores a serem considerados para a escolha do estilo de liderança a ser adotado, tais como mudanças ambientais, novas tendências de mercado, alterações de classe econômica e da estrutura do setor onde a organização está inserida, políticas governamentais, inovação tecnológica, dentre muitos outros que podem influenciar nos resultados da organização. 
De acordo com Bernardi (2010) o empreendedor pode ser um líder, pois liderar é algo que se aprende. O autor define alguns perfis de líderes, tais como: exigente, liberal, nato, inovador, social, normal, herdeiro, corporativo autoritário, serial entre outros.

Já Tzu (2005, p. 53) cita que "Em geral, dirigir muitos é quase igual a dirigir poucos. Depende somente da organização" isso infere que a capacidade de liderar independe do tamanho da equipe, mas sim da maneira como a executa.

França (2006) ainda complementa que a liderança significa planejamento, mudança, desenvolvimento e direcionamento de subsistemas sociais, onde as atividades de liderança diferem sistematicamente de acordo com o ambiente organizacional.

Dessa forma, a liderança é a ação de conduzir os funcionários para o alcance dos objetivos da empresa, é saber explicar e conduzi-los a atingir o que é esperado deles.

\subsubsection{Importância da Liderança}

Desde o pós-guerra as organizações se deram conta de que já não era mais possível continuar tentando fazer com que pessoas trabalhassem em ambientes opressivos e passaram a valorizar situações nas quais pudessem utilizar ao máximo todo o potencial dos seus colaboradores (BERGAMINI, 2009). Contudo, nos dias de hoje, conforme Chiavenato (2006), o homem deixou de ser comparado a uma máquina para ser um fator indispensável à organização.

Desde então, a importância e o valor de um líder se fazem sentir praticamente em todas as direções dentro das organizações e não somente pelo grupo de colaboradores. Segundo Bennis (1996, p. 22):

Os líderes são importantes por três motivos: em primeiro lugar, eles são responsáveis pela eficácia das organizações. O sucesso ou fracasso de qualquer organização. Em segundo, as adversidades que encontramos pelo caminho às vezes nos deixam sem rumo, então buscamos nos líderes um caminho, um porto seguro. E em terceiro lugar, o líder é aquele que conhece o problema, mas não se prende ao contexto, seja ele por conta dos cenários administrativos voláteis ou fusões e aquisições ou ainda por fatores demográficos. 
Ainda, a importância de um líder se mostra na conservação de um bom clima organizacional. Segundo Chiavenato (2006, p. 52), "o clima constitui o meio interno de uma organização, a atmosfera psicológica é a característica que existe em cada organização". Ou seja, o clima é o ambiente humano, no qual as pessoas de uma organização fazem seus trabalhos.

Destaca-se, também, que uma boa liderança pode auxiliar na diminuição dos custos de uma empresa, como o custo com rotatividade. Segundo Chiavenato (2006), "a rotatividade de pessoal não é uma causa, mas um efeito, a consequência de certos fenômenos localizados interna ou externamente à organização que condicionam a atitude e o comportamento do pessoal".

Por meio dos autores acima citados, pode-se perceber o quanto a liderança é imprescindível para um bom andamento dos negócios, se a liderança não for introduzida de forma correta pode trazer problemas, como: absenteísmo, clima organizacional ruim, desmotivação dos funcionários, sentimento de desvalorização entre outros. Por isso o líder deve ser um indivíduo centrado, com pensamento humanístico, paciente, responsável para assim dar um bom exemplo aos colaboradores, que tenha bastante conhecimento para ganhar o respeito e admiração dos mesmos.

Logo, a liderança vem tornando-se cada vez mais importante, pois é através de um líder que uma equipe se motiva a realizar suas funções com êxito, e consequentemente, geram resultados satisfatórios para a organização. (PEREZ E OLIVEIRA, 2015).

\subsubsection{Tipos de Liderança}

Os estilos de liderança dizem respeito ao comportamento do líder no exercício da sua função (WRIGHT, 2011). Existem diversos tipos de liderança, deve-se verificar quais tipos mais apropriados para equipe a qual esse líder irá liderar.

Os tipos de liderança são: afetiva, autoritária, liberal, autocrática, democrática, carismática, diretiva, participativa, transacional, situacional, cognitiva, entre outras. (MAXIMIANO, 2010).

Cada uma dessas lideranças demonstram um tipo de comportamento do líder frente a seus subordinados dentro de uma empresa. Assim, para a elaboração desse estudo, serão 
abordados os tipos de liderança situacional e liderança cognitiva, de forma a avaliar se, de fato, são os modelos ideais para restaurantes franceses.

\subsubsection{Liderança Situacional}

Um dos tipos de liderança que será evidenciado neste trabalho é a liderança situacional, a qual, em diversos estudos de caso, se mostrou um modelo altamente eficaz e cada vez mais importante nas empresas dos mais variados ramos, apresentado com resultados favoráveis e de fácil aceitação perante os funcionários. Isso porque esse tipo de liderança foca tanto no aspecto das relações humanas quanto na produtividade dos colaboradores.

É um modelo de liderança elaborado por Hersey e Blanchard, na década de 80, e que permite ao líder tomar decisões com maior segurança e apoio por parte de toda a organização, decisões estas que consideram o nível de maturidade do colaborador e o ambiente de trabalho como essenciais para o sucesso da organização, propiciando ao líder exercer sua liderança adequando estilos de liderança diferentes conforme as situações encontradas (QUAGLIO, 2015).

O conceito básico da liderança situacional consiste na premissa de que não existe um único estilo de liderança apropriado para toda e qualquer situação. O líder, liderados e a situação são as variáveis norteadoras do processo de liderança; entretanto, neste modelo a ênfase recai sobre o comportamento do líder em relação aos liderados frente a uma tarefa específica (GALVÃO et al.,1998). Ou seja, para Hersey; Blanchard (1986), um líder não terá eficácia se não adequar seu estilo de liderança às necessidades diárias. Mesmo considerado todas as variáveis como relevantes, na liderança situacional o foco é o comportamento do líder em relação ao liderado.

O que diferencia este tipo de liderança das demais são as habilidades do líder em identificar o perfil do liderado, considerando o seu desempenho atual nas atividades desenvolvidas, não pela pessoa humana que é ou no seu potencial, e sim ter conhecimento sobre os diversos perfis de liderança para usá-los, um ou outro, nos momentos mais oportunos. A percepção dos seus liderados sobre suas estratégias, vai depender do nível de maturidade destes e como se prontificarão a receber este modelo de liderança (QUAGLIO, 2015). Em suma, caberá ao líder avaliar a maturidade de cada liderado, e a maturidade geral de seu grupo, se necessário. (HERSEY; BLANCHARD, 1986). 
Com isso, pode-se inferir que o que mais marca a liderança situacional é sua flexibilidade em mudar, na qual as características em devida situação dependerão da gravidade, do comportamento do liderado e do cenário vivido. Tais características devem estar presentes em um restaurante, em que a pressão e as adversidades são constantes e uma liderança flexível poderá trazer grande impacto positivo.

\subsubsection{Liderança Cognitiva}

Outro tipo de liderança que se encaixa exatamente à ideia desse estudo sobre restaurantes, é a Liderança Cognitiva, em que o líder é visto como um membro da equipe que trabalha junto com os colaboradores visando o bem-estar da empresa. A participação presente do líder faz toda diferença para o bom andamento de um restaurante.

Segundo o Dicionário Escolar da Língua Portuguesa (2015, p.152), Cognição é o ato ou processo de conhecer, que envolve atenção, percepção, memória, raciocínio, juízo, imaginação, pensamento e linguagem. A palavra cognição tem origem nos escritos de Platão e Aristóteles.

Liderança Cognitiva é aquela que o líder se envolve, trabalha junto e percebe as pessoas ao seu redor, ritmo individual e coletivo, propondo desafios e responsabilidades que verdadeiramente estimulam, motivam e fazem os resultados serem possíveis e crescentes (ORTEGA, 2021).

Este modelo de liderança defende que para conseguir estimular seus profissionais e fazê-los ir na direção que acredita ser a melhor, o líder precisa criar um ambiente apropriado, seguro, onde as pessoas sintam-se confiantes, motivadas, empoderadas em decorrência disso. Assim, entende-se que a liderança cognitiva conecta os pontos e tem como objetivo criar um clima favorável para a execução das tarefas e alcance das metas diárias (MARQUES, 2016).

O que se espera da liderança cognitiva é que ocorra uma queda no índice de absenteísmo, que o clima organizacional seja mais agradável e que líderes e liderados tenham uma boa comunicação, trabalhando juntos em prol do sucesso do empreendimento. O clima organizacional é algo perceptível para os clientes, se eles perceberem gritos, ofensas, estresse, tristeza entre os colaboradores, o atendimento e a qualidade da comida acabam sendo afetados. 


\subsection{Ambiente Organizacional}

Independentemente do ramo, as empresas possuem seu ambiente físico e interno. $\mathrm{O}$ ambiente interno tem um grande impacto no atingimento das metas traçadas. Cabe aos líderes administrarem e analisarem o ambiente organizacional para resolver problemas, identificar oportunidades e riscos para suas organizações.

Quando se trata de restaurantes, a estrutura deve-se apresentar impecavelmente limpa, boa claridade, temperatura agradável e fluxo livre para os garçons transitarem. 0 ambiente tem que ser confortável para o cliente se sentir bem.

Há autores que definem o ambiente organizacional apenas como ambiente externo. Segundo Oliveira (2007) o ambiente organizacional pode ser compreendido como o conjunto de todos os fatores externos à organização que de maneira indireta e direta, proporcionam ou recebem influência da organização.

Na divisão de ambiente, de acordo com Sobral e Peci (2012), tem três tipos de ambiente: Ambiente Geral, Ambiente Operacional e Ambiente Interno.

O Ambiente Geral é composto pelos participantes que não sofrem interferência da organização, São eles: ações políticas, tecnologia, ações econômicas e sociais.

O Ambiente Operacional é parte do ambiente externo que pode agregar no alcance dos objetivos da organização, os componentes que podem influenciar positivamente ou negativamente são os fornecedores, clientes e concorrentes (NASCIMENTO et al; 2010).

O Ambiente Interno é o conjunto dos elementos internos da organização como: Cultura organizacional, estrutura organizacional e instalações físicas e os colaboradores (NASCIMENTO et al; 2010). Já segundo Oliveira (2007), o ambiente interno tem como propósito levantar pontos fortes, fracos e neutros que a empresa possui, analisando seus produtos e serviços.

Segundo Sobral e Peci (2012, p.72), "esses três elementos influenciam a adequação da organização ao ambiente externo, consequentemente, o desempenho organizacional". A análise, para alcance das metas parte da gestão que deve mensurar os pontos fracos, fortes e oportunidades.

De acordo com essa ideia entende-se que o ambiente interno e o externo devem ser acompanhados pelos gestores, que são pessoas responsáveis e capazes de identificar as 
oportunidades e os riscos dos ambientes. A avaliação de cada setor organizacional dar-se por sua estrutura, do seu tamanho e de sua forma (NASCIMENTO et al; 2010).

Independente da estrutura há uma necessidade de manter-se uma comunicação entre colaborador e gestor, conquistando a confiança dos colaboradores, onde todos passam a focar no objetivo da organização.

\subsection{Clima Organizacional}

Maximiano (2010) afirma que o Clima Organizacional em essência é uma medida de como as pessoas se sentem em relação à empresa e seus administradores, tendo seu conceito evoluído para o conceito de qualidade de vida no trabalho.

Já para para Judge, Robbins e Sobral (2011), o Clima Organizacional faz menção das percepções que os colaboradores de uma organização têm sobre ela e seu ambiente de trabalho. De forma a complementar, Ferreira (2013) afirma ainda que o clima pode ser entendido como a percepção da atmosfera da organização e impacta a satisfação no trabalho, as interações entre os grupos e o comportamento que afastam os colaboradores do ambiente de trabalho.

Enquanto isso, uma empresa é produtiva quando alcança seus objetivos, transformando matéria-prima num produto que obtenha o menor custo possível. (JUDGE; ROBBINS E SOBRAL, 2011). Em um restaurante, a produtividade pode se dar, por exemplo, no tempo médio de preparação de pedidos, taxa de entregas dentro do prazo e o tempo médio de espera de um cliente.

Com isso em vista, para uma organização, o sentimento de satisfação das pessoas para com à empresa é um fator de extrema importância, o qual poderá resultar em melhores resultados devido à alta motivação. Judge; Robbins e Sobral (2011) explicitam isso em seus estudos, quando afirmam que as organizações onde predomina a satisfação com o trabalho aproximam-se de um melhor desempenho.

Em suma, como trazem Judge; Robbins e Sobral (2011), "funcionários felizes são funcionários mais produtivos". Dessa forma, o investimento em um clima organizacional agradável terá uma correlação com o desempenho no trabalho. 
Ademais, entende-se que as lideranças tem um papel crucial em organização para a concretização de um bom clima organizacional, sendo responsáveis, além dos resultados de seus liderados, por entende-los e contribuir de forma estratégica para os seus bem-estar.

\subsection{Gastronomia Francesa}

Quando se fala de culinária e gastronomia, a comida francesa se destaca com seus sabores simples, os quais são complexos em refinamento. A pedra angular da cozinha francesa chama-se planejamento, composto por métodos de organização, de disposição de utensílios, de corte e de pré-cozimento de ingredientes.

O site Sabor a Vida (2019) relata um conceito que fala sobre a organização da cozinha francesa. "A mise en place, significa "tudo em seu lugar". Essa frase exemplifica o básico para se atingir o auge da arte de cozinhar: possuir pleno controle dos ingredientes e ferramentas antes de começar a preparar os alimentos.

Assim, percebe-se que a gastronomia francesa preza pela organização da cozinha para, com isso, começar a preparar os pratos. O ponto inicial será limpar, organizar, separar tudo que for necessário, para só então começar a cozinhar.

Trabalhar com gastronomia exige uma boa dose de organização, planejamento, pesquisa, ética, profissionalismo e comprometimento. Não adianta ser apenas uma pessoa que sabe cozinhar bem, pois ao se deparar com um evento para 500 pessoas, por exemplo, se não tiver o conhecimento de como gerenciar todas as etapas de produção, o resultado final pode ser catastrófico (MIESSA, 2013).

Não basta apenas o conhecimento culinário técnico, gerir um restaurante necessita de uma visão holística, ou seja, um conhecimento de um todo. Somente assim o líder terá controle de todas as etapas do restaurante e, como resultado, obterá clientes e colaboradores satisfeitos.

A cozinha francesa foi declarada patrimônio imaterial da humanidade em 2010 pela UNESCO mostrando sua importância e representatividade. Assim como a cultura e costumes do país, a gastronomia francesa é lembrada pelos indivíduos e conhecedores de uma boa refeição (LEAL, 1998), e tem influenciado a cozinha de outros países (GAMBATO \& GONÇALVES, 2017). 
Este foi o caso da cozinha Mexicana no século XIX, que impulsionada pela burguesia ansiosa pela sofisticação buscou profissionais e receitas francesas que foram incluídas nos menus do México (BAKGELLER, 2009).

De fato, Poulain (2004) aponta que a partir do século XVII, a cozinha francesa disseminou-se de uma forma mais sistemática por meio de escritos como livros, receituários, listas de pratos, tornando-se quase uma linguagem culinária com suas diversas matizes e tipos de cozinhas.

Os restaurantes franceses têm uma boa fama em todo o mundo, e a França recebe milhares de turistas por todo o país, assim como na Polinésia Francesa, especializada em turismo de luxo e alta gastronomia. A liderança dos chefes de cozinha é algo muito importante para o bom andamento desses estabelecimentos que tem um fluxo de pessoas de várias origens, onde a qualidade, organização e limpeza serão fundamentais.

A riqueza de detalhes aliada à simplicidade desses locais atrai os amantes da culinária e do ambiente francês. Por isso, apostar no estilo é uma excelente forma de diferenciar o seu estabelecimento no mercado brasileiro (OLIVEIRA, 2006). 


\section{Metodologia}

Neste capítulo será explicitado detalhadamente os processos da coleta de dados e informações referentes ao assunto para, com isso, obter conteúdo suficiente para elaboração das demais fases deste estudo. O capítulo em questão contempla o método de pesquisa utilizado e todos os andamentos do processo para obtenção de resultados.

\subsection{Metodologia de pesquisa utilizada}

Segundo Marconi; Lakatos (2017) a pesquisa científica é um conjunto de procedimentos sistemáticos, apoiado no raciocínio lógico e que usa métodos científicos para encontrar soluções para problemas pesquisados. A pesquisa científica é muito importante pois é responsável pela aquisição da produção de conhecimento. É por meio dela que os pesquisadores entendem o mundo e solucionam problemas que transformam o mundo em que vivemos.

Quanto à natureza da pesquisa, os dados foram coletados por meio da pesquisa qualitativa, utilizando como procedimentos metodológicos uma abordagem descritiva e exploratória, em uma entrevista estruturada fechada, associada à pesquisa bibliográfica em livros, artigos, teses e dissertações.

No que diz respeito aos meios de investigação, optou-se pela pesquisa de campo, aliada a observação direta, que, também de acordo com Vergara, é: "investigação empírica realizada no local onde ocorre ou ocorreu um fenômeno ou que dispõe de elementos para explicá-lo. Pode incluir entrevistas, aplicação de questionários, testes e observação participante ou não" (VERGARA, 2009, p.43).

A pesquisa qualitativa foi realizada através de entrevista e observação direta que segundo Mota (2019), a entrevista é definida como um processo de interação social entre duas pessoas na qual uma delas, o entrevistador, tem por objetivo a obtenção de informações por parte do outro, o entrevistado. A entrevista como coleta de dados sobre um determinado tema científico é a técnica mais utilizada no processo de trabalho de campo. A observação direta também é considerada uma coleta de dados para conseguir informações sob determinados aspectos da realidade. Ela ajuda o pesquisador a identificar e obter provas a 
respeito de objetivos sobre os quais os indivíduos não têm consciência, mas que orientam seu comportamento (BONI; QUARESMA, 2005).

Após a definição dos meios de pesquisa, foi feita a elaboração de quatro perguntas para guiar a entrevista e, assim, obter as informações necessárias para o estudo. As perguntas ajudaram a atender os objetivos gerais e específicos deste artigo.

A primeira pergunta era a seguinte: "Que tipo de liderança combina mais como o modelo de liderança a qual atua?". Tais tipos de liderança foram explicados aos entrevistados de forma simples e clara, pois sabe-se que nem todos conseguem identificar e intitular o tipo de liderança adotado por si próprio.

A segunda pergunta procurou saber se os líderes desses restaurantes estavam satisfeitos com o clima organizacional. Essa pergunta foi essencial para compreender a visão do chefe quanto à sua equipe.

Já a terceira pergunta questiona qual o foco da organização de sua cozinha. Assim, buscando compreender as estratégias buscadas pelos chefes.

Depois da elaboração das perguntas, concentrou-se em traçar e escolher o perfil dos entrevistados, buscando perfis que saberiam responder as questões evidenciadas. Com isso, foi decidido, também, que a amostra seria de três restaurantes de cozinha francesa. Então, para participar, o entrevistado teria que ser líder em um restaurante no Rio de Janeiro ou no Tahiti.

Para encontrar profissionais com o perfil desejado, usou-se a rede social profissional Linkedln que, segundo os autores Rodrigues e Filho (2019), é uma rede social diferente do Facebook e o Instagram que são mais voltadas para o entretenimento, sendo que o foco do Linkedln é o mercado de trabalho.

Além das entrevistas, foram utilizados também dois tipos de questionários, um direcionado ao chefe, e outro direcionado a seus cozinheiros. Teve-se como referência quatro restaurantes, sendo dois no Rio de Janeiro e dois no Tahiti. Após isso, dentro de cada restaurante, foi colocado o questionário para o chefe de cozinha e para mais dois cozinheiros diretos. Foram obtidas, com isso, doze respostas. 


\subsection{Procedimento e instrumento de coleta de dados}

A coleta contou com a participação de quatro líderes em restaurante de culinária francesa e um cozinheiro, sendo três líderes e um cozinheiro no Rio de Janeiro e outro líder no Tahiti. Para captar o perfil pretendido, necessitou-se analisar as informações disponibilizadas na própria rede social Linkedln do indivíduo, ou seja, antes de enviar o convite para participar da pesquisa, o profissional era avaliado se realmente se encaixava ao perfil desejado.

Primeiro, foi escolhido o chefe e professor Yves Dhieras, o qual atualmente atua como chefe responsável pelo restaurante do Lycée Hôtelier e du Tourisme de Tahiti. Além disso, ele é o diretor e professor da mesma instituição. Yves se formou em gastronomia em Paris, já foi chefe em diversos restaurantes da França e, ao final da carreira optou por morar no Tahiti, onde há uma formação gastronômica idêntica à formação francesa.

O segundo escolhido foi o brasileiro Fabiano Dias, fundador da Dias Assessoria Gastronômica, que presta consultoria para diversos restaurantes no Rio de Janeiro. Fabiano se formou em gastronomia na Universidade Estácio de Sá e já passou por todos os níveis hierárquicos de uma cozinha, trabalhando em diversos restaurantes do Rio de Janeiro e optando, posteriormente, pela prestação de consultoria, na qual viu a oportunidade de melhorar o modelo de negócio dos restaurantes cariocas. Atualmente, ele presta consultoria em todas as funções de um restaurante, direcionando seus clientes a um modelo de negócio saudável.

O terceiro entrevistado foi o chefe francês Yann Kamps, professor chefe da escola de gastronomia Le Cordon Bleu, no Rio de Janeiro.

O quarto entrevistado foi Jonas Ferreira, formado pela uma das melhores escolas de gastronomia do mundo, Ferrandi em Paris. E atualmente é chefe do restaurante Le Cordon Bleu e Professor do Instituto Le Cordon Bleu do Rio de Janeiro.

Por fim, o quinto entrevistado foi João Camargo, fundador da pâtisserie Do João, formado pelo Instituto Le Cordon Blue, em Botafogo. Atualmente, trabalha como cozinheiro no único restaurante duas estrelas Michelin, do Rio de Janeiro, Oteque.

Assim, as entrevistas foram feitas por meio da abordagem qualitativa, a qual requer um cuidado intensificado com as informações coletadas, sendo o tipo de abordagem que 
exige intepretações acerca das respostas obtidas. Ou seja, é mais intangível e aberta, diferente da abordagem quantitativa, que é baseada em dados mensuráveis.

A pesquisa qualitativa não se preocupa com representatividade numérica, mas sim, com o aprofundamento da compreensão de um grupo social, de uma organização, entre outros.

Os pesquisadores que adotam a abordagem qualitativa opõem-se ao pressuposto que defende um modelo único de pesquisa para todas as ciências, já que as ciências sociais têm sua especificidade, o que pressupõe uma metodologia própria. Assim, os pesquisadores qualitativos recusam o modelo positivista aplicado ao estudo da vida social, uma vez que o pesquisador não pode fazer julgamentos nem permitir que seus preconceitos e crenças contaminem a pesquisa (GERHALDT; SILVEIRA, 2009).

As entrevistas foram realizadas nos restaurantes que os líderes trabalham e/ou por via de redes sociais. A conversação foi informal, de forma a propiciar que os entrevistados se sentissem à vontade para responder as questões levantadas. Permitiu-se fazer a observação direta, em que os entrevistados gentilmente apresentaram todo o ambiente: recepção, salão e cozinha.

\subsection{Limitações do estudo}

As dificuldades que nortearam a coleta de dados foram representadas pela pandemia do Covid-19, a falta de resposta aos convites enviados para participar da pesquisa e do filtro seleto das características necessárias, ou seja, não bastava ser restaurante, teria que ser especializado em cozinha francesa. Sendo assim, a pesquisa é relativamente pequena, porém contém informações claras, objetivas e fidedignas.

Foram obtidas cinco entrevistas bem detalhadas a respeito dos assuntos, sendo localizados no Rio de Janeiro e no Tahiti. Todos são restaurantes de médio porte, com atendimento delivery e bem conhecidos.

Houve uma certa negação dos demais restaurantes, que não queriam se expor, pois com todas as consequências geradas pela pandemia, piorou-se muito o modelo de negócio. Outros também alegaram falta de tempo para fazer entrevista já que, por causa da pandemia, houve mudanças no quadro de funcionários e no horário de funcionamento, sobrecarregando os funcionários que permaneceram. 


\section{Análise dos Dados}

\subsection{Entrevistas}

Foram realizadas cinco entrevistas, com três brasileiros, dois chefes de cozinha e um cozinheiro, além de dois chefes de cozinha franceses. Os cinco destacaram a importância de um planejamento e organização para o bom funcionamento da cozinha.

Todos concordaram e sentiram, após as conversas, a necessidade de um estudo mais elaborado sobre liderança focado numa cozinha de restaurante, pois é um local diferente de qualquer outro ambiente de trabalho.

Normalmente, o ambiente de uma cozinha é quente, apertado, onde se lida com produtos com temperaturas adversas (muito quente ou muito frio), materiais perigosos. Esses fatores citados podem tornar o ambiente mais estressante, o que deixa o líder com um papel ainda mais importante, o de administrar esses fatores e ao mesmo tempo, manter um clima organizacional amistoso.

\subsubsection{Que tipo de liderança combina mais com você e como é o modelo de liderança atual, em sua cozinha?}

A pergunta inicial buscava entender o tipo de liderança que os chefes de cozinha seguiam. Dentro da entrevista, ao apresentar as lideranças contingencial e situacional, ficou claro que os todos adotam esses estilos de liderança e confirmaram que seria ideal o estudo mais aprofundado, focado em cozinhas de restaurante, para melhorar o funcionamento de uma cozinha. Esses pontos se mostram evidentes de acordo com alguns trechos da entrevista:

Conforme Fabiano Dias afirmou na entrevista (2021), “(...) já se passou esse tempo de chefe abusador. Acho que o mais importante agora é entender meus funcionários e adaptar meu jeito de tratar cada um, de acordo com seus jeitos e habilidades individuais. $\mathrm{E}$ isso é o que tem gerado mais resultado para gente nos últimos tempos". O trecho demonstra como o uso da liderança situacional - adaptável - pode gerar valor e resultados. 
Já em outro trecho, o mesmo complementa: “(...) e claro que, dependendo do dia, precisamos focar mais na entrega do resultado, ao invés de pensar no clima, mas é tudo questão de saber balancear". A liderança contingencial se mostra presente em sua fala.

Conforme Yves Dhieras afirmou na entrevista (2021), “(...) sou um chefe particularmente diferente de meus colegas de trabalho, busco em primeiro lugar entender meus funcionários, adaptar suas habilidades e interesses, nos processos necessários para minha cozinha. Durante minha experiência na escola de gastronomia francesa, vi que os chefes são formados muito militarmente. A grande preocupação é o comprimento da tarefa, e não a melhor utilização do funcionário. Já vi diversos funcionários talentosíssimos serem demitidos pois tentarem melhorar os processos do chefe.".

Com essa frase, Yves deixa claro não estar satisfeito com a cultura de liderança francesa e, mesmo sem nunca ter ouvido falar em liderança situacional, ele se comporta de acordo com ela.

Conforme João Camargo afirmou na entrevista (2021) “(...) sofro muito com o clima estressante de uma cozinha de restaurante, interfere diretamente em minha produtividade e satisfação. Por um tempo achei, vendo a maioria dos restaurantes cariocas, que era indispensável ser estressante, e acabei resolvendo sair da cozinha de um restaurante grande, para criar minha própria Pâtisserie. Mas mudei muito e hoje trabalho no restaurante Oteque, onde o chefe Alberto Landgraf me dá total liberdade de atuação e opinião. Ele é um chefe que busca adaptar seu menu às habilidades individuais dos seus cozinheiros, buscando apenas orientar a forma de realizar o processo, dando o exemplo de como se faz, porém, totalmente aberto à mudança, escutando todos os cozinheiros, para sempre estar melhorando seus processos, e tornar o trabalho mais fluido.".

Ao analisarmos a teoria contingencial, onde o líder deve ser parte da equipe, dando o exemplo como um ensinamento, o restaurante Oteque se mostrou utilizar dessa filosofia. $O$ restaurante Oteque trabalha com um menu degustação, que se adapta à sazonalidade dos ingredientes, buscando sempre a utilização do insumo mais fresco e mais saboroso, adaptando sempre seu menu ao melhor andamento interno da cozinha.

Conforme Yann Kamps afirmou na entrevista (2021): “(..) trabalhei com diversos chefes na França, e aprendi a liderar com eles, acho que não existe somente um estilo de liderança para uma cozinha, eu nunca estudei sobre liderança".

Já Jonas Ferreira afirmou na entrevista (2021): “(...) a profissão de chefe não existe, a profissão é cozinheiro, chefe é uma posição que vai se trabalhando ao longo da vida, até 
atingir um conhecimento técnico pessoal e interpessoal e alguém dar um voto de confiança para você se tornar chefe de cozinha. Liderar sem perder a humanidade é o meu lema".

Analisando essa afirmação notou-se que a formação de um líder se faz no caminho da profissão, e não é ensinada no curso de gastronomia, e sim aprendida através da observação e experiencia. A capacidade de lidar com pessoas é um ponto fundamental saber trabalhar em grupo, o que diz a teoria situacional e cognitiva.

\subsubsection{Qual o nível de satisfação dos líderes quanto ao clima organizacional?}

João Camargo e Yves Dhieras se mostraram satisfeitos com o clima organizacional de seus restaurantes. Já Fabiano Dias mostrou que nem sempre é possível ter um clima organizacional saudável dentro da cozinha brasileira.

Destaca-se a afirmação de Fabiano (2021), “(...) já tivemos problemas antes, e acredito que ainda vou ter problemas futuros com os cozinheiros brasileiros. A maioria dos cozinheiros disponíveis no mercado carioca são muito brutos, e não tem nada a perder, muito menos tem a responsabilidade necessária para gerir os riscos de uma cozinha. Já presenciei diversas vezes brigas físicas entre cozinheiros, e em ocasiões mais extremas ameaças fortes, com os materiais perigosos, como facas e líquidos quentes, isso exemplifica a alta rotatividade de funcionários nos restaurantes cariocas, muitos não sabem controlar suas emoções. Com a redução do meu quadro de funcionário, fiz uma boa seleção dos melhores e nos últimos meses eu venho tentando ouvir mais a equipe, preocupado em não perder ninguém. Isso vem mostrando resultado, hoje acredito produzir mais e melhor, com menos gente." Ele cita também uma época em que, de fato, tinha uma liderança mais rígida, com explosões de raiva, o que, contudo, não era a melhor forma de resolver os impasses.

Analisando esse trecho da entrevista do Fabiano Dias, nota-se que o mercado de cozinheiros no Brasil ainda é muito desigual, a maioria dos cozinheiros não têm nenhuma formação, aprendem no campo, buscam uma subida na hierarquia da cozinha, e um salário um pouco melhor, e os poucos cozinheiros que têm qualificação, ou têm seus próprios negócios ou estão em locais de trabalho mais agradáveis.

Destaca-se também a afirmação feita por Yves “(...) o cozinheiro na França é muito valorizado, além de ser muito bem formado. Raramente um cozinheiro sem formação prévia, consegue permanecer em uma cozinha francesa. Isso gera um comportamento muito 
individualista, raramente vamos ver um cozinheiro francês ajudando o seu parceiro, sem que antes seja solicitado. Os cozinheiros têm um respeito muito grande com a hierarquia e são muito disciplinados."

Para Yves, essa individualidade dentro da cozinha francesa é extremamente benéfica para o bom funcionamento das engrenagens da cozinha.

Quanto ao clima organizacional, ele acredita não ser dos melhores. Yves diz ser raro ver os franceses sendo solícitos com seus colegas, ficam restritos às suas funções.

Analisando essas informações, a falta de uma organização de processos, além de uma pouca flexibilidade para lidar com seus funcionários, pode gerar um trabalho precário.

Destaca-se também a afirmação feita por João na entrevista (2021) “(...) fui trabalhar no Oteque, pois o chefe de cozinha se mostrou interessado com minhas habilidades, e preocupado em ouvir minhas ideias, dando liberdade para opinar sobre a realização dos processos, mudando metodologias se fosse necessário para uma melhor experiencia gastronômica final do cliente." Analisando essa frase, percebe-se que João se preocupa muito com um clima organizacional flexível, onde é necessário adaptar os processos de uma cozinha ao cozinheiro que está realizando a tarefa. Para ele cada indivíduo tem suas peculiaridades e é preciso respeitá-las e valorizá-las. Esse trecho se encaixou perfeitamente com as teorias situacionais citadas por Hersey e Blanchard.

\subsubsection{Qual o foco da sua organização da sua cozinha?}

O tópico dividiu opiniões. Fabiano Dias acredita que sua equipe ainda é inexperiente, portanto, precisa ter um foco maior no ensino, na organização e controle das atividades. Segundo o trecho da entrevista (2021) “(...) o cozinheiro desqualificado não tem nada a perder, e não tem interesse em fazer as coisas bem-feitas, ele busca fazer o mínimo possível, e trabalhar menos tempo, mas venho buscando dar mais autonomia para alguns funcionários que mostrem um bom desempenho.".

Enquanto isso Yves Dhieras busca apenas orientar seus cozinheiros, dando o exemplo, apenas quando necessário. Ele busca passar de forma bem clara, uma organização de tempos, processos, metas e responsabilidades, aos seus cozinheiros, no início do serviço. Acredita muito em sua equipe, já que ela é bastante autônoma e consegue desempenhar atividades com a responsabilidade necessária. Yves também mostrou uma boa escuta para 
com sua equipe, ajudando apenas quando é solicitado. Para ele é importante que todos sejam responsáveis em suas funções.

João também mostrou que o foco de uma cozinha é a organização, o mise en place, e o marche en avant, citados nas teorias de organização francesas, são as palavras chaves importantes para o bom funcionamento de uma cozinha. Para ele o importante é cada item estar em seu lugar, e uma função só começar após a finalização da outra.

Conforme Yann Kamps afirmou na entrevista (2021): “(...) A organização da cozinha é primordial, e por isso existe uma brigade de cuisine. A brigada de cozinha foi criada por Auguste Escoffier. Ele se inspirou no exército francês, para teorizar o sistema hierárquico da cozinha, no modelo da brigada militar. A distribuição de tarefas evita descuidos, negligencias e perdas de tempo, também faz parte da organização da cozinha, la marche en avant (marcha em frente) é um princípio fundamental para garantir a higiene e a segurança alimentar da sua cozinha profissional, antes de tudo é uma questão de organização e sua aplicação é um ganho na produtividade diária.

Conforme Jonas Ferreira (2021): “(...) o foco da organização é conseguir conciliar todos os elementos para uma experiencia gastronômica, é ter um bom sabor, preço bom, ser bem servido e os garçons estarem atentos.".

\subsubsection{Quais as habilidades de liderança são mais adequadas a um chefe de cozinha?}

O tópico dividiu opiniões, e cada um acredita em habilidades diferentes. A importância de uma flexibilidade para trabalhar em uma cozinha de restaurante é um ponto e outro ponto é como não há habilidades pré-definidas para ser um bom líder. Porém, uma habilidade que apareceu de forma unânime nas entrevistas, foi: ser uma pessoa bastante organizada, e se mostrar um membro da equipe, disposto a ajudar ao que for necessário, para que tudo seja realizado como planejado.

Segundo a entrevista de Yves (2021) “(...) se adaptar às adversidades de uma cozinha, é um dos skills (habilidades) mais importante, além de ser bem-organizado. Durante o serviço a cozinha de restaurante necessita uma organização rígida em relação aos tempos de preparo e a qualidade da realização do processo. Sem essa rigidez, durante o serviço, os processos se perdem nos tempos e geram uma grande bola de neve, atrasando e piorando a qualidade final dos pratos servidos". 
Segundo a entrevista de Fabiano Dias (2021), a habilidade mais importante é voltada ao psicológico, focada em entender seus funcionários, sendo flexível para adaptar suas necessidades às habilidades de cada um. Outra habilidade importantíssima para Fabiano é "dar o exemplo".

Já segundo a entrevista com João Camargo (2021) “(..) para mim, um bom líder é aquele que sabe expor suas necessidades, de forma calma e clara, buscando sempre ajudar quando vê um atraso em algum processo, aliviando ao máximo a pressão que já existe naturalmente dentro de uma cozinha, e proporcionando ao cozinheiro tempo para ele poder realizar um trabalho bem-feito".

De acordo com a entrevista de Yann Kamps (2021): “(...) se você se adapta e proporciona a flexibilidade, você perde o padrão, e como chefe tem que estabelecer esse padrão para fidelizar o cliente. O bom cozinheiro é aquele que consegue consertar o erro mostrando sua criatividade e caráter".

Conforme Jonas Ferreira, durante a entrevista (2021): “(...) é preciso saber lidar com pessoas, orquestrar um organismo que é a cozinha, e saber que é um trabalho coletivo, ter um caráter formador, saber que cada um tem sua missão, e que é plenamente possível ter uma cozinha competente, com alta gastronomia, sem utilizar de abusos e recorrer a humilhações. Sensibilidade, confiança, cumplicidade, dar reconhecimento financeiro, quando percebe o valor do funcionário, clareza nas relações, e escuta dos seus funcionários, são os principais pontos".

\subsection{Questionário}

Para um maior levantamento de dados, dois questionários foram aplicados em cozinhas brasileiras e Taitianas. Para tanto, foram utilizados questionários separados em dois, um direcionado ao chefe de cozinha, e outro direcionado a seus cozinheiros. Assim, tendo como referência restaurantes franceses, no Rio de Janeiro e no Tahiti.

Esse questionário está focado em analisar se, de fato, existe a necessidade de uma boa liderança, e se a liderança situacional e contingencial são as melhores. O questionário visa mostrar se os funcionário e/ou chefes veem se o estilo de liderança está ligado ao bom funcionamento da cozinha. O resultado do questionário aplicado foi o seguinte: 
Primeiramente foi aplicado os questionários ao restaurante Coco's, no Tahiti, destinado ao chefe, István Soós. E outro questionário direcionado a dois cozinheiros da mesma cozinha, Natuanui Boosie e Simon Augendre. Depois foi escolhido o Restaurante White, direcionando o questionário ao chefe Christophe Delsaux, e a dois cozinheiros da mesma cozinha, Yuri Moraes e Alann Poilvet.

Posteriormente foi escolhido mais dois chefes e professores da escola de gastronomia francesa, Le Cordon bleu, Salvador Ariel Lettieri e o Pablo Peralta (chefe do restaurante Le Cordon Bleu) para responder ao questionário dos chefes. E mais três alunos e cozinheiros, Diana Vidal, João Camargo e Miguel Fiuza Gentil, para responder aos questionários para os cozinheiros. Foi selecionado também Frederic Monnier, chefe de cozinha francês, para responder ao questionário dos chefes.

O questionário do chefe continha quatro perguntas, e respostas sim ou não: "Você estuda, ou já estudou, estilos de liderança?"; "Acredita que a liderança é importante para um bom negócio?"; "Está satisfeito com o clima organizacional de seu restaurante?"; "O clima organizacional interfere na sua produtividade?".

Já o questionário dos cozinheiros conta com cinco perguntas e respostas sim ou não: "Você estuda, ou já estudou, estilos de liderança?"; "Acredita que a liderança é importante para um bom negócio?"; “Está satisfeito com o clima organizacional de seu restaurante?"; "O clima organizacional interfere na sua produtividade?"; "Quando o líder delega uma tarefa para você, ele (na maioria das vezes) leva em consideração suas habilidades e interesses?”.

Após a aplicação dos questionários, foi feita uma análise comparativa entre o chefe e os cozinheiros de um mesmo restaurante. Ainda, comparou-se os restaurantes franceses no Tahiti com os restaurantes brasileiros.

\subsection{Análise de Entrevistas e Questionários}

\subsubsection{Comparação do estilo de liderança entre restaurantes brasileiros e restaurantes franceses}

\subsubsection{Percepção acerca dos questionários}


Serão, então, analisados os resultados do questionário. A primeira análise feita foi sobre a importância da liderança e do clima organizacional pelos chefes e cozinheiros, e como isso pode os influenciar.

Gráfico 1: Questionário chefe francês (2021).

vous étudiez les styles de leadership?

2 respostas

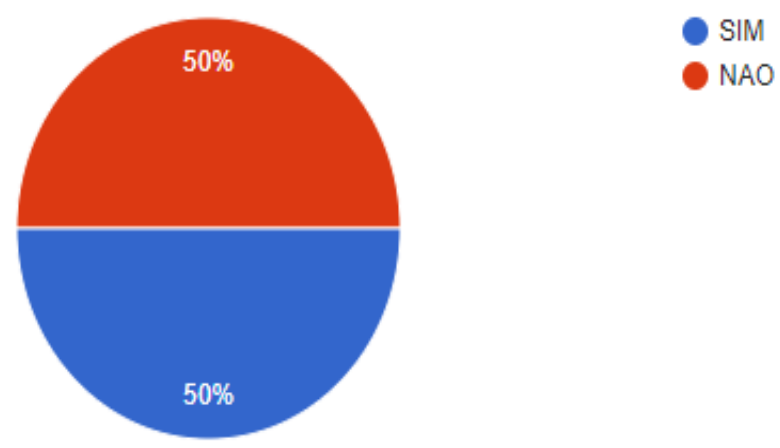

Fonte: Autor (2021).

Gráfico 02: Questionário chefe brasileiro (2021)

Você estuda, ou já estudou, estilos de liderança?

3 respostas

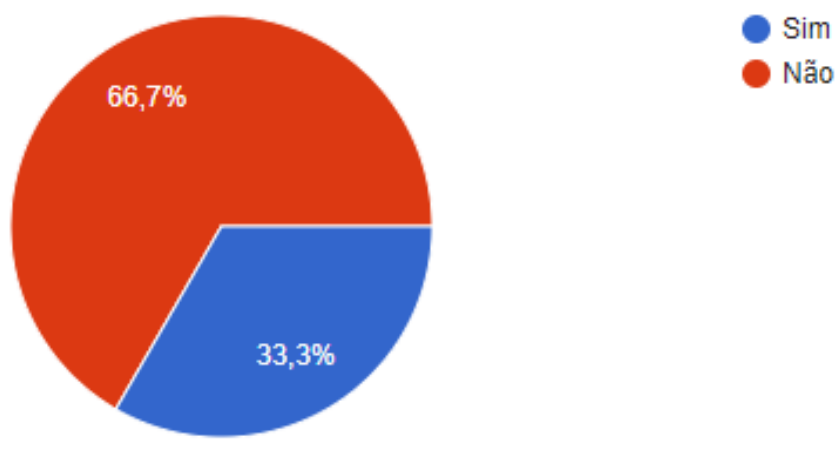

Figura 2: Autor (2021)

Gráficos 1 e 2: Nota-se nesses gráficos que a maioria dos chefes nunca estudou especificamente estilos de liderança e que a preocupação em estudar esses estilos veio a partir de suas experiencias profissionais. 
Gráfico 3: Questionário cozinheiros brasileiros (2021).

Você estuda, ou já estudou, estilos de liderança?

3 respostas

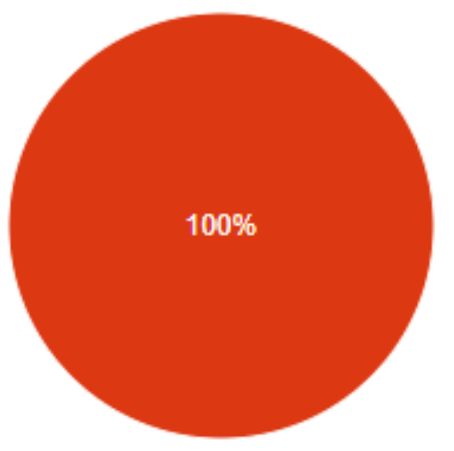

Sim

Não

Fonte: Autor (2021).

Gráfico 4: Questionário cozinheiros franceses (2021).

vous étudiez les styles de leadership?

4 respostas

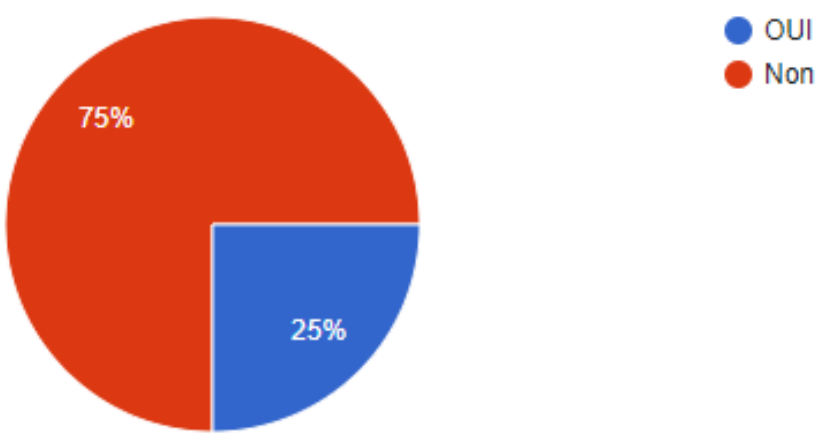

Fonte: Autor (2021)

Gráfico 4: Quando analisamos as respostas dos cozinheiros, percebe-se como o estudo sobre liderança não existe no curso de gastronomia. A maioria dos cozinheiros são recémformados, e afirmaram nunca ter estudado modelos de liderança.

Comparando os cozinheiros do Brasil aos da França, nota-se que temos apenas um cozinheiro que se preocupa em estudar a liderança, e ele é francês. 
Gráfico 5: Questionário cozinheiros franceses (2021).

Croit que le leadership est important pour une bonne entreprise?

4 respostas

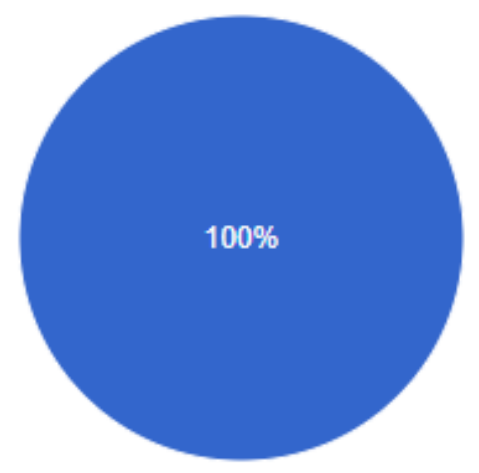

OUI

Non

Fonte: Autor (2021).

Gráfico 6: Questionário cozinheiros franceses (2021).

Croit que le leadership est important pour une bonne entreprise?

2 respostas

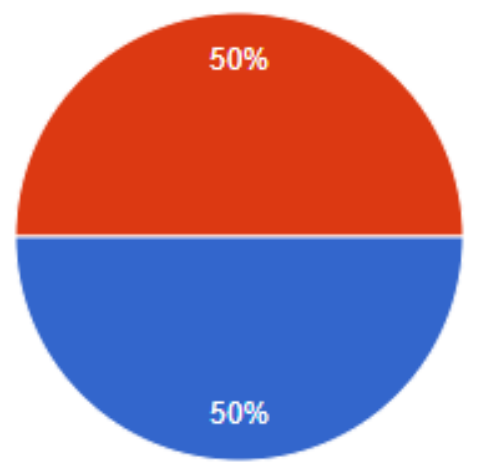

SIM

- NAO

Fonte: Autor (2021). 
Gráfico 7: Questionário chefe brasileiro (2021).

Acredita que a liderança é importante para um bom negócio?

3 respostas

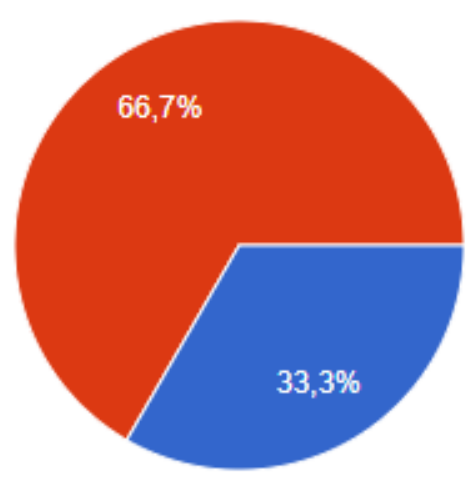

Sim

Não

Fonte: Autor (2021).

Gráfico 8: Questionário cozinheiros brasileiros (2021).

Acredita que a liderança é importante para um bom negócio?

3 respostas

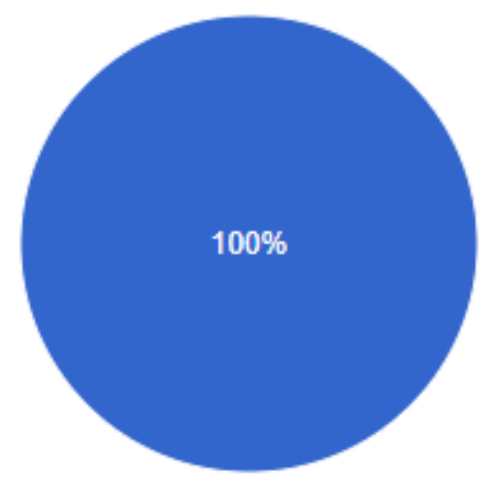

Sim

Não

Fonte: Autor (2021).

Gráfico 8: A maioria dos chefes e cozinheiros, tanto do Brasil quanto da França, acreditam que a liderança é importante para um bom negócio. Porém, ao analisar os estilos de liderança em seus restaurantes, nem sempre foi considerada como satisfatória. Ou seja, todos acreditam que a liderança é importante, porém nem todos conseguem exercer a liderança necessária. 
Gráfico 9 e 10: Questionários cozinheiros franceses (2021).

Est satisfait du climat organisationnel de son restaurant?

4 respostas

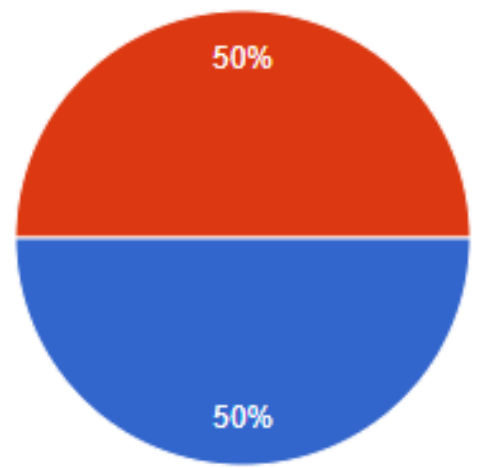

OUI

Non

Le climat organisationnel interfère avec votre productivité?

4 respostas

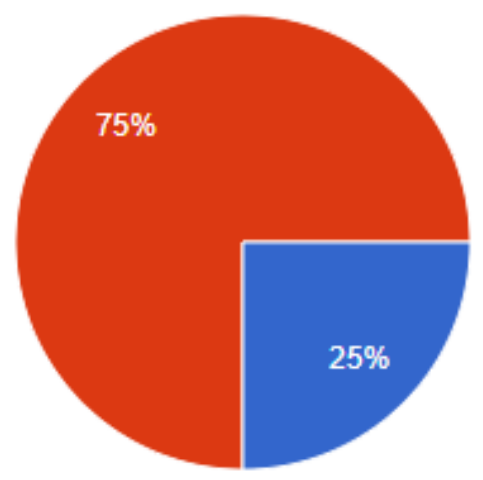

OUI

- Non

Fonte: Autor (2021). 
Gráficos 11 e 12: Questionários cozinheiros franceses (2021).

Est satisfait du climat organisationnel de son restaurant?

2 respostas

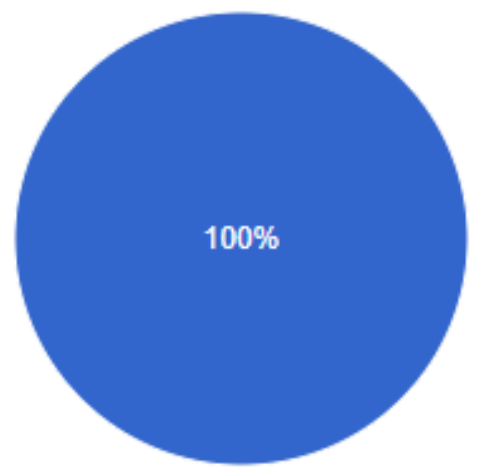

SIM

NAO

Le climat organisationnel interfère avec votre productivité?

2 respostas

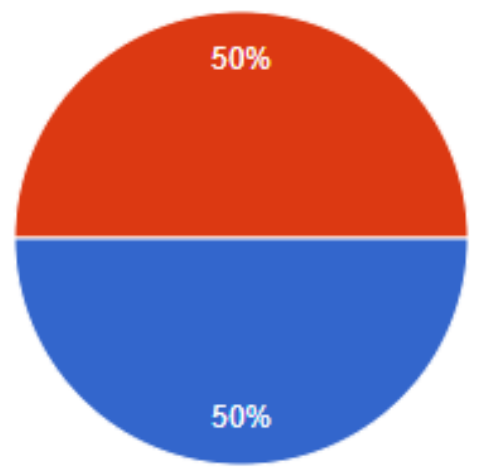

SIM

NAO

Fonte: Autor (2021).

Gráficos 11 e 12: Ao analisar as respostas dos cozinheiros franceses, percebe-se que eles não se preocupam com o clima organizacional, a maioria se considera competente o suficiente para realizar suas tarefas. 
Gráficos 13 e 14: Questionários cozinheiros brasileiros (2021).

Está satisfeito(a) com o clima organizacional do seu restaurante? 3 respostas

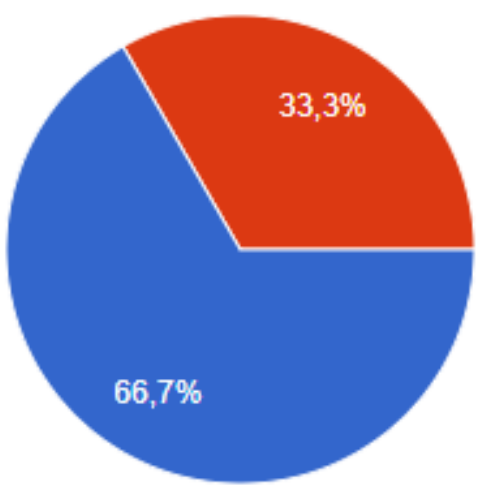

Sim

Não

O clima organizacional interfere na sua produtividade?

3 respostas

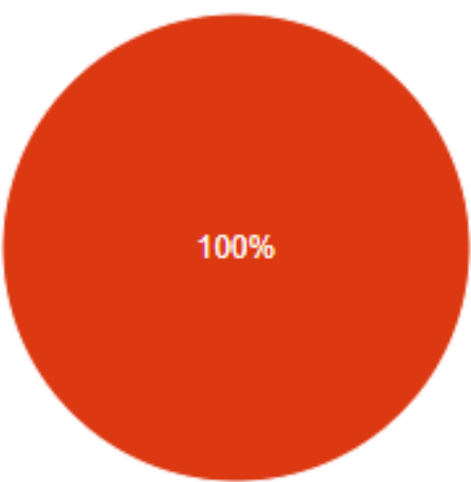

Sim

Não

Fonte: Autor (2021). 
Gráfico 15 e 16: Questionários cozinheiros brasileiros (2021).

Está satisfeito(a) com o clima organizacional do seu restaurante?

3 respostas

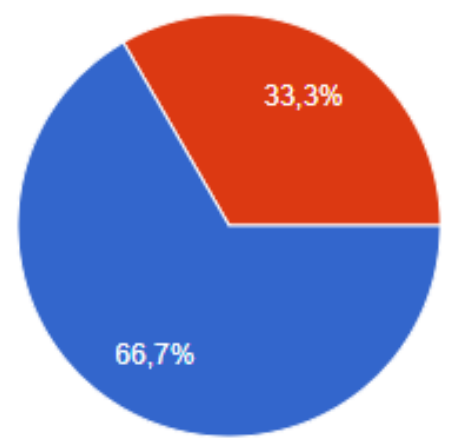

Sim

Não

O clima organizacional interfere na sua produtividade?

3 respostas

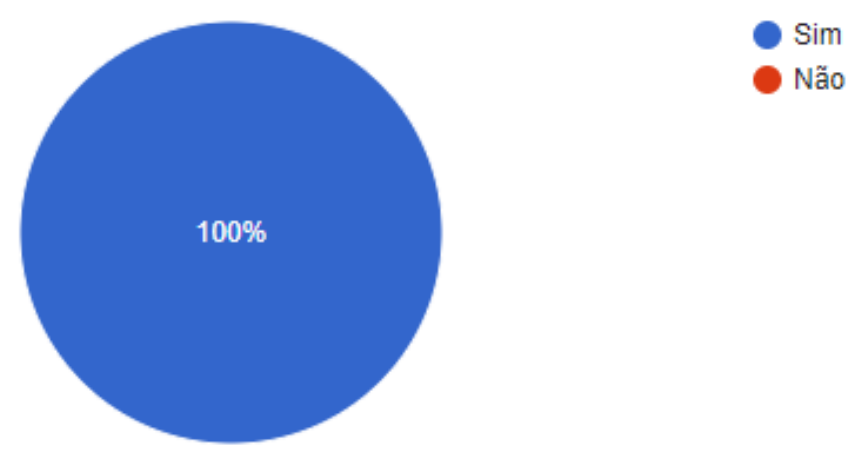

Fonte: Autor (2021)

Gráficos 15 e 16: Percebe-se o quanto é necessário um bom clima organizacional para a realização das atividades. $100 \%$ dos cozinheiros brasileiros dizem que o clima interfere diretamente na sua produtividade. 
Gráficos 17 e 18: Questionário cozinheiros franceses (2021).

Lorsque votre chef vous délègue une tâche, prend-il (la plupart du temps) en compte vos compétences et vos intérêts?

4 respostas

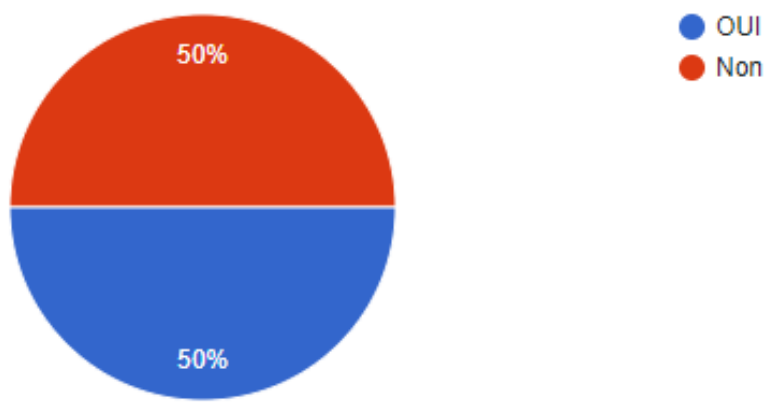

Comment traitez-vous avec vos employés?

2 respostas

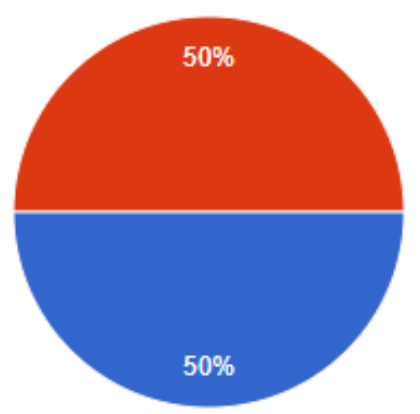

Je donne de l'ordre et j'espère que le travail est bien fait

Je cherche à m'adapter à chaque employé, cherchant à comprendre l'employé

Je fais partie de l'équipe, je le ferai ensemble si j'en ai besoin

J'essaye de t'expliquer et te montrer comment

Fonte: Autor (2021)

Gráficos 17 e 18: Analisando as respostas, percebe-se que os chefes acreditam que apenas dar ordens já é o suficiente, classificando-os como não flexíveis e rígidos.

Gráfico 19: Questionário chefe brasileiro (2021).

Como lida com seus funcionários?

3 respostas

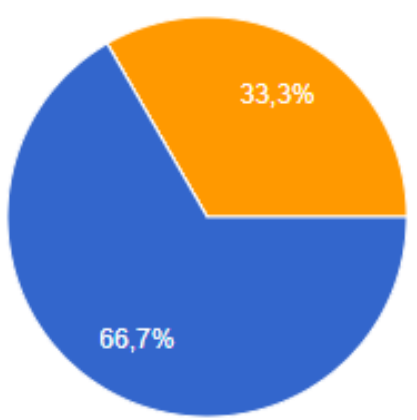

Dou ordens, e espero o trabalho bem feito

Tento explicar e mostrar como faz

Sou parte da equipe, faço junto com eles

- Busco me adaptar a cada funcionário, buscando o melhor entendimento do mesmo

Fonte: Autor (2021). 
Gráfico 20: Questionários cozinheiro brasileiro (2021).

Quando seu lider delega uma tarefa para você, ele (na maioria das vezes) leva em consideração suas habilidades e interesses?

3 respostas

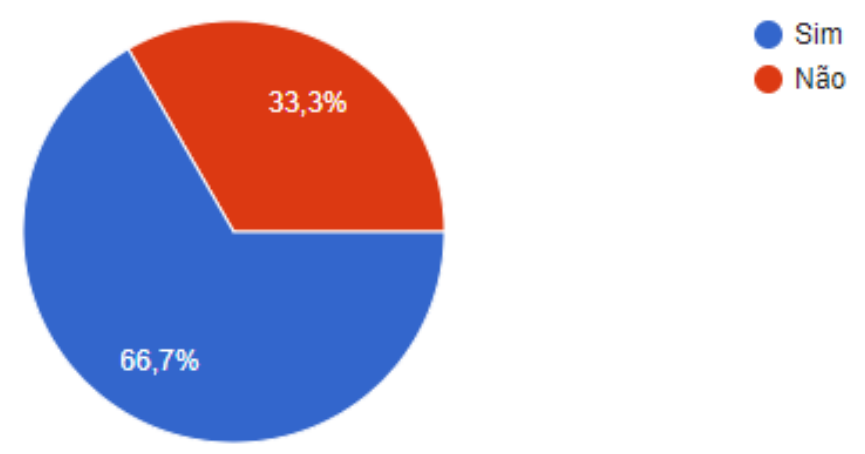

Fonte: Autor (2021).

\subsubsection{Percepção acerca das entrevistas}

Em primeira instância, nota-se que o curso de gastronomia nunca se preocupou em ensinar estilos de liderança, já que os chefes que estudaram, afirmaram terem buscado conhecimento por conta própria fora da grade de gastronomia.

Quando perguntado o motivo pelo qual os chefes buscam estudar liderança, de forma geral, esses afirmaram ser devido à sua formação em boas escolas e com bons líderes, em que perceberam a necessidade de uma boa liderança para obter grandes resultados.

Segundo Jonas Ferreira, a cozinha francesa tem uma legislação muito diferente da brasileira "os franceses têm estatísticas e indicadores muito confiáveis, porque é uma atividade essencial para a economia do país. Em média os franceses se alimentam $70 \%$ do ano fora de casa, excluindo os turistas, já no Brasil, temos vários problemas de legislação tanto na parte trabalhista quanto na gestão do negócio, em relação a impostos e segurança alimentar. Na França tem um senso de hierarquia muito mais rígido que o brasileiro".

O comportamento francês, mais rígido e militarizado e pouco flexível, gera uma atmosfera opressiva onde pode ocasionar abusos, que prejudicam um bom funcionamento no organismo da cozinha. 
Para uma cozinha saudável, é importante alinhar as expectativas entre o chefe e seus funcionários. Um bom líder com funcionários que não correspondam a expectativa desse líder, também não serve.

\subsubsection{Impacto do estilo de liderança estudado sobre o clima organizacional}

\subsubsection{Percepção acerca dos questionários}

A análise seguinte tem como objetivo compreender se um líder adaptável (que fosse flexível de acordo com a situação - Liderança Situacional) possui correlação com um clima organizacional positivo.

Dessa forma, pegou-se a amostra de ambos os questionários sobre a pergunta "Quando seu líder delega uma tarefa para você, ele (na maioria das vezes) leva em consideração suas habilidades e interesses?".

Quando analisamos as respostas dos cozinheiros desses restaurantes vimos que a preocupação do chefe com as necessidades dos cozinheiros é suficiente para estabelecer um bom clima organizacional. Causando também uma diferença entre as interpretações entre o que o chefe pensa e o que os cozinheiros consideram relevantes.

Enquanto isso, no restaurante Coco's, representado pelo chefe Istvan, e seus cozinheiros Natuanui e Simon, mostraram não estar satisfeitos com o clima organizacional. Comparando as respostas do chefe com os cozinheiros, Istvan se diz satisfeito com o clima organizacional, porém seus cozinheiros não.

Isso nos faz notar que Istvan gosta de um clima organizacional mais agressivo e rígido, enquanto seus cozinheiros aceitam esse clima, mesmo se não concordam com ele. Natuanui e Simon, se mostram preocupados em adaptar suas habilidades às necessidades do chefe, enquanto Istvan apenas se preocupa em comandar independente da preferência de seus funcionários.

Ainda, percebe-se que há uma diferenciação nas respostas de restaurantes brasileiros e franceses sobre o impacto de uma liderança.

Quanto a pergunta sobre a consideração do chefe em relação às habilidades e interesses para delegar uma tarefa, os cozinheiros responderam positivamente. 
Ainda, durante as entrevistas, foi-se evidenciado que apenas o chefe Christophe Delsaux, na França, e Yves Dhieras, no Brasil, já estudaram estilos de liderança e, de forma semelhante, os dois disseram que estudaram por conta própria, ao perceber em sua experiencia o quanto se melhora a produtividade da cozinha quando se entende seus funcionários e se mostra parte da equipe, priorizando em dar o exemplo, ao invés de dar ordens.

Ao analisar se estão satisfeitos com o clima organizacional e se esse clima interfere em sua produtividade, os chefes brasileiros e franceses dividiram opiniões. Na França, a maioria dos chefes não se preocupa com o clima organizacional pois dizem que esse clima não interfere na sua produtividade. Para eles, a produtividade tem que existir independente do clima, e se não está sendo produtivo não é por motivos do clima, e sim porque não tem interesse na produção.

Analisando essas respostas, os chefes franceses são "profissionais" ao ponto de realizar suas tarefas independente do clima, e que o clima organizacional na verdade é uma consequência de uma boa realização dos processos.

Nos restaurantes Coco's, o chefe está satisfeito com o clima organizacional, porém seus cozinheiros não estão. Ao conversar com os cozinheiros, vimos que eles demonstram não estar satisfeitos com o chefe, pois ele não os escuta. Disseram ter "medo da opinião do chefe", dizendo que ele "é extremamente grosseiro, e não está nem aí para a felicidade ou entendimento".

É preciso a preocupação com a realização final dos processos. O sistema francês se mostrou autoritário, sem a menor flexibilidade e exigente com o resultado.

\subsubsection{Percepção acerca das entrevistas}

Ao comparar as respostas com a entrevista, nota-se que é possível observar esses aspectos também em alguns trechos, como quando o chefe brasileiro, afirma que "apenas recentemente comecei a olhar melhor para essa questão de liderança, depois de alguns problemas internos que tivemos". Enquanto isso, o chefe francês, Yves, conta que raramente há problemas relacionados à equipe, e a maioria das dificuldades são resolvidas no diálogo. Comparando também com a entrevista do João, onde afirma ter saído dos restaurantes por não estar satisfeito com o clima organizacional, e que escolheu trabalhar no restaurante Oteque, pela boa relação que tem com o chefe. 
Os chefes que já estudaram liderança, são os chefes que buscam entender seus funcionários, e se preocupam com eles. O chefe Christophe, no Tahiti, respondeu "procuro me adaptar aos cozinheiros, e compreender meus funcionários" enquanto o chefe Salvado Ariel, no Brasil, respondeu "sou parte da equipe, faço junto com eles".

Dessa forma, é evidente a importância de um clima organizacional e a liderança para a satisfação dos colaboradores e funcionários.

Com as análises, conclui-se que, de fato, os estilos de liderança situacional e contingencial provocam um melhor clima organizacional, além de ainda ser necessário um maior estímulo ao aprendizado sobre liderança no setor. 


\section{Conclusão}

Comparando os estilos de cozinha francesa e brasileira, concluímos que, na cozinha francesa não existe um único estilo de liderança e sim uma liderança de acordo com as necessidades de cada negócio. Para os franceses, o mais importante é a organização e sistematização, com uma estrutura hierárquica bem definida, como uma Brigade de cuisine (brigada de cozinha) onde todos sabem o que fazer, e isso que gera produtividade e ganhase tempo.

La marche en avant (caminhando para a frente), que dizer, um trabalho só se começa quando se finaliza o anterior, para garantir a higiene, a segurança alimentar e a padronização. De acordo com a cultura francesa, a padronização do produto é importante para fidelizar o cliente.

$\mathrm{Na}$ cozinha brasileira existe uma preocupação com o clima organizacional e uma disposição ao aprendizado, já que poucos cozinheiros receberam um aprendizado formal. Por outro lado, a criatividade compensa a falta de informação, e a proatividade e disposição para o trabalho em grupo, pode chegar a um bom resultado.

No meu entender, o melhor líder é o que sabe reunir os melhores elementos para chegar ao melhor resultado possível, enfatizando que as características de uma cozinha são muito especificas: temperaturas extremas, local geralmente pequeno, materiais perigosos, uma grande pressão em relação ao tempo de entregas, e imediatismo na tomada de decisão. Saber lidar com seus funcionários, sem precisar se utilizar de nenhuma forma de abuso, trabalhar com cozinheiros competentes, ter um nível de exigência muito alto, sem precisar recorrer a humilhações. O velho estilo de liderança autoritária deu passagem para uma liderança horizontal, onde todos os membros da equipe são valorizados e respeitados em suas habilidades e conhecimentos. Esse modelo mais horizontal está sendo muito aplicado no Vale do Silício, onde estão situadas as principais startups mundiais. Isso mostra a grande mudança da percepção da liderança.

O equilíbrio entre e a formação francesa, com sua padronização das tarefas, e respeito à hierarquia, divisão de trabalho e a criatividade da cozinha brasileira, com seus diversos sabores e habilidades nas relações interpessoais, é o que acredito que esse trabalho coloca em evidência. 
Para uma boa saúde de um restaurante, é bom manter um clima descontraído onde todos tenham consciência de pertencer a um mesmo organismo, apresentando um trabalho de qualidade.

Percebe-se, por fim, que adaptar o seu estilo de liderança e estar atento às individualidades de cada membro da equipe, de fato, tem uma alta correlação com o clima organizacional - em que os líderes que se adaptam conseguem equipes com maiores rendimentos.

O presente trabalho foi voltado para a liderança devido a sua importância no contexto de uma empresa. Os diversos estudos de liderança é uma proposta para o cenário gastronômico brasileiro. Para tanto, os estilos de liderança situacional e contingencial foram o foco da pesquisa, e ambos mostraram resultados positivos. Assim, resta o estímulo da empresa para que líderes e liderados busquem aprender cada vez mais sobre o tema. 


\section{Referências}

BAK-GELLER CORONA, S. Los recetarios 'afrancesados' del siglo XIX en México. Anthropology of food S, v. 6, 2009.

BENNIS, W. A formação do líder. São Paulo: Atlas, 2016.

BERNARDI, Luiz Antônio. Manual de empreendedorismo e gestão: fundamentos estratégias e dinâmicas. ed. Atlas, 2010.

CHIAVANETO, Idalberto; Introdução à Teoria Geral da Administração. Rio de Janeiro: Elsevier, 2003.

CHIAVENATO, Idalberto. Administração de Recursos Humanos: Fundamentos básicos. 6ª ed. São Paulo: Atlas, 2006.

Dicionário Escolar da Língua Portuguesa. 1 ed. Barueri, SP: Ciranda Cultural, 2015.

FRANÇA, Ana Cristina Limongi. Comportamento organizacional: conceitos e práticas. ed. Saraiva, 2006.

GAMBATO, Cristian; GONÇALVES, Roberto Birch. Adaptação da cozinha francesa a cultura e o paladar brasileiro. Cultur, ano 11. n 03, out/ 2017.

GALVÃO, Cristina Mari; TREVIZAN; Maria Auxiliadora; SAWADA; Namie Okino; COLETA; José Augusto Dela. Liderança situacional: estrutura de referência para o trabalho do enfermeiro-líder no contexto hospitalar. Rev. Latino-Am. Enfermagem vol.6 no.1 Ribeirão Preto, 1998.

GERHALDT, Tatiana Engel; SILVEIRA, Denise Tolfo. Métodos de Pesquisa. 1 ed. Editora UFRGS: Rio Grande do SUL, 2009.

HERSEY, P.; BLANCHARD, K.H. Psicologia para administradores: a teoria e as técnicas da liderança situacional. Trad. Edwino A. Royer. São Paulo: Editora Pedagógica e Universitária, 1986.

MARQUES, Elaine Sereno; SILVA, Luzielma Oliveira da; ESTENDER, Antonio Carlos; NERY, Sandi; BOCK, Cláudia Patrícia. A importância do desenvolvimento da liderança. Gestão da tecnologia para a competitividade. São Paulo: 23, 24 e 25 de outubro de 2013.

MARQUES, José Roberto. O que é Liderança Cognitiva. Disponível em https://www.jrmcoaching.com.br/blog/o-que-e-lideranca-cognitiva/. Acesso em 22 de abril de 2021.

MAXIMIANO, Antônio Cesar Amaru. Teoria geral da administração: da revolução urbana a revolução digital. ed. Atlas, 2010.

MIESSA, Vanessa Prestes. Introdução a Gastronomia. Instituto Federal do Paraná, 2013. 
NASCIMENTO, Aldeiza de Oliveira; SOUSA Laís Gomes de Sousa Lucas Gomes de; CRUZ Lucineide. As pessoas e 0 ambiente organizacional. Disponível em https://administradores.com.br/artigos/as-pessoas-e-o-ambiente-organizacional. Acesso em 22 de abril de 2021.

OLIVEIRA, Djalma de Pinho Rebouças de. Planejamento Estratégico: Conceitos, Metodologia, Prática. 23. td. São Paulo: Atlas, 2007.

OLIVEIRA, Mario da Silva. Gestão de restaurantes: uma prática de hospitalidade. 2006. 113 f. Dissertação (Mestrado em Planejamento e Gestão Estratégica em Hospitalidade) Universidade Anhembi Morumbi, São Paulo, 2006.

ORTEGA, Marcelo. Liderança Cognitiva. Disponível em https://www.catho.com.br/carreirasucesso/colunistas/marcelo-ortega/lideranca-cognitiva/. Acesso em 22 de abril de 2021.

PEREZ, Olivia Cristina; OLIVEIRA, Ana Paula Modesto. Liderança eficaz: o poder e a influência de um líder no comportamento organizacional de uma empresa. Administração de empresas em revistas. e-ISSN: 2316-7548. v. 1, n. 10, 2015.

QUAGLIO, Marcos Honori; CASTRO, Adriana Sperandio Ventura Pereira de; RODRIGUES, Alexsandro dos Santos; CONTIN, Neri Rodrigues. Liderança situacional: uma abordagem teórica a partir do modelo de Hersey e Blanchard. Revista Eletrônica Produção \& Engenharia, v. 7, n. 1, p. 575-586, Jul./Dez. 2015.

ROBBINS, S. P.; JUDGE; T. A.; SOBRAL, F. Comportamento Organizacional. 14a․ ed. São Paulo: Pearson Prentice Hall, 2011.

SOBRAL, Felipe; PECI, Alketa. Fundamentos da Administração. São Paulo: Pearson, 2012.

TZU, Sun. A arte de guerra. São Paulo: Martin Claret, 2005.

WRIGHT, Peter L. Administração estratégica conceitos. 12ำ reimpressão, São Paulo: Ed. Atlas. 